\title{
Is There a Way to Predict Granulosa Cell Tumor of the Ovary? The Role of Peripheral Blood Test Parameters
}

\author{
Overde Granüloza Hücreli Tümörü Tahmin Etmenin Bir Yolu Var mı? \\ Periferik Kan Testi Parametrelerinin Rolü \\ Muzaffer Seyhan Çıkman ${ }^{1}$, İsmet Gün ${ }^{1 \oplus}$, Önder Sakin ${ }^{1 \oplus}$, Kazibe Koyuncu ${ }^{1 \oplus}$, Ali Doğukan Anğın ${ }^{1 \oplus}$ \\ Ateş Karateke ${ }^{2 \oplus}$, Enis Özkaya ${ }^{2 \oplus}$ \\ ${ }^{1}$ University of Health Sciences Dr. Lütfi Kırdar Kartal Training and Research Hospital, Department of Gynecology and Obstetrics, Istanbul, \\ Turkey \\ ${ }^{2}$ University of Health Sciences Zeynep Kamil Training and Research Hospital, Department of Gynecology and Obstetrics, Istanbul, Turkey
}

Received: 20 February 2020 / Accepted: 24 February 2020 / Publication date: 26 March 2020

Cite as: Çıkman MS, Gün I, Sakin Ö, Koyuncu K, Doğukan Anğın A, Karateke A, Özkaya E. Is there a way to predict granulosa cell tumor of the ovary? The role of peripheral blood test parameters. Med J Bakirkoy 2020;16(1):56-61

\section{ABSTRACT}

Objective: As the clinical characteristics and clinical presentation of granulosa cell tumour of the ovary (GCTO) are not specific, predictive markers are required. The aim of this study was to evaluate the use of peripheral blood parameters in the preoperative prediction of GCTO.

Method: This retrospective case-control study included 34 patients with GCTO (Group 1) and 158 females with benign ovarian mass (Group 2). Data were recorded and the groups were compared in respect of age, gravida, parity, neutrophil- to- lymphocyte ratio (NLR) and platelet- to- lymphocyte ratio (PLR) and red cell distribution width (RDW).

Results: With the exception of age, no difference was determined between the groups in respect of the other demographic parameters. In the study group, the RDW values were lower and NLR and PLR were higher than in the control group. The differences between the groups were statistically significant ( $p=0.003, p=0.013, p=0.038$, respectively). The cutoff values obtained from the ROC curve for RDW, NLR and PLR were 14.3, 2.03 and 129.3, respectively. RDW was the only marker with sensitivity (67.6\%) and specificity (65.8\%) over $60 \%$. In the study group a positive correlation was determined between tumour diameter and NLR ( $r=0.46, p=0.006)$. Conclusion: Although increased RDW is a strong determinant of mortality, including cancer-related deaths, the results of this study showed decreased RDW in GCTO. Low RDW could possibly be used as a screening tool in GCTO.

Keywords: granulosa cell tumor, red cell distribution width, ovary

öz

Amaç: Granüloza hücreli over tümörünün (GHOT) klinik özellikleri ve sunumu spesifik olmadığından, prediktif belirteçler gereklidir. Bu çalışmanın amacı, preoperatif GHOT'nü öngörmede periferik kan parametrelerinin kullanımını değerlendirmektir.

Yöntem: Bu retrospektif vaka kontrol çalışması, GHOT'ü olan 34 hasta (Grup 1) ve benign ovaryen kitlesi olan 158 kadın (Grup 2) üzerinde yapıldı. Hastaların yaş, gravida, parite, nötrofil-lenfosit oranı (NLO), trombosit-lenfosit oranı (PLO) ve kırmızı hücre dağııım genişliği (RDW) dahil olmak üzere preoperatif verileri kaydedildi ve gruplar arasında karşıllaştırıldı.

Bulgular: Demografik parametreler, yaş hariç, gruplar arasında farklılık göstermedi. Çalışma grubunda kontrol grubuna göre RDW düşük, NLO ve PLO daha yüksekti. Gruplar arasındaki farklar istatistiksel olarak anlamlıydı (sırasıyla 0.003, 0.013 ve 0.038). RDW, NLO ve PLO için ROC eğrisinden elde edilen kesim noktaları sırasıyla 14.3, 2.03, 129.3'tü. RDW duyarlılık ve özgüllügü \% 60'ın üzerinde olan tek belirteçti (sırasıyla \% 67.6 ve \% 65.8). Olgu grubunda tümör çapı ile NLO arasında pozitif korelasyon vardı $(r s=0.46, p=0.006)$. Sonuç: Artmış RDW, kansere bağlı ölümler de dahil olmak üzere güçlü bir mortalite belirleyicisi olmasına rağmen, bu çalışmanın sonuçları GHOT'nde RDW'nin azaldığını göstermiştir. Düşük RDW muhtemelen GHOT'nde bir tarama aracı olarak kullanılabilir.

Anahtar kelimeler: granüloza hücreli tümör, kırmızı küre dağılım genişliği, over

Corresponding Author:

kazibekkoyuncu@gmail.com
M. S. C.kman 0000-0003-2485-568X i. Gün 0000-0002-5371-5339

Ö. Sakin 0000-0001-6036-9975

K. Koyuncu 0000-0001-9070-3962

A. Doğukan Anğın 0000-0003-1954-8546

A. Karateke 0000-0002-0199-6474

E. Özkaya 0000-0001-6580-1237

(C) Telif hakkı Sağlık Bilimleri Üniversitesi Bakırköy Dr. Sadi Konuk Eğitim ve Araştırma Hastanesi'ne aittir. Logos Tıp Yayıncılık tarafindan yayınlanmaktadır. Bu dergide yayınlanan bütün makaleler Creative Commons Atff-GayriTicari 4.0 Uluslararası Lisansı ile lisanslanmıştr.

(c) Copyright Health Sciences University Bakırköy Sadi Konuk Training and Research Hospital. This journal published by Logos Medical Publishing.

Licenced by Creative Commons Attribution-NonCommercial 4.0 International (CC BY-NC 4.0) 


\section{INTRODUCTION}

Granulosa cell tumour of the ovary (GCTO) is formed of somatic cells of the sex cord ${ }^{(1)}$. GCTO is an uncommon form of cancer, constituting $5 \%$ of all ovarian malignancies ${ }^{(2)}$. There is a relationship between GCTO and hyperoestrogenisation-related symptoms such as postmenopausal bleeding, which renders early diagnosis possible ${ }^{(3)}$. The clinical characteristics and presentation of GCTO are not specific, and diagnosis is based on the histopathological evaluation of tissue obtained during surgery.

According to the clinical presentation and histological pathology, there are two types of GCTO; the pediatric form and the adult form. The adult type is seen at the rate of $95 \%$ and generally in females aged $50-54$ years ${ }^{(4,5)}$. Unlike epithelial ovarian cancers, GCTO is characterised by a good prognosis (1).

Peripheral blood examination is cheap, repeatable and is sufficient for diagnosis in some patients. When screening methods are limited in patients, such as for cancer, the full blood count is promising for assisting in clinical decision-making. The accumulated evidence has shown that the inflammatory micro-environment related to the tumour facilitates tumour growth and metastasis ${ }^{(6)}$. White blood cells contained in the mature leukocyte spectrum include lymphocytes, neutrophils and monocytes. There is lymphocytic suppression in the peripheral blood of more than half of malignant cases. The lymphocyte reaction plays a critical role in the immune response and is also an influential factor in the suppression of cancer progression. The neutrophil mechanisms in proliferation and metastasis include the expression of reactive oxygen species or nitric oxide and the remodelling of the extracellular matrix ${ }^{(7)}$.

Platelets contribute to the inflammatory reaction by increasing angiogenesis or releasing growth factors. To predict prognosis and the potential for malignancy of adnexial masses during preoperative period, inflammatory markers such as the neutrophil- tolymphocyte ratio (NLR) and platelet- to- lymphocyte ratio (PLR) have been examined ${ }^{(8-10)}$. A previous study reported that NLR was a predictor for GCTO (11). RDW is a part of the routine full blood count and reflects the heterogenity of the red blood cell dimensions. Previous studies have shown that RDW is a strong indicator of all mortality causes, including cancer-related deaths ${ }^{(12,13)}$.

The aim of this study was to investigate preoperative predictive parameters of adult-type GCTO, using the full blood count values of NLR, PLR, RDW, and mean platelet volume (MPV).

\section{MATERIAL and METHODS}

\section{Design}

Approval for the study was granted by the local ethics committee of a tertiary health care center in Istanbul. Hospital records were retrospectively reviewed for the period between January 2006, and June 2015.

Exclusion criteria were defined as a history of local or systemic infection, chronic diseases such as diabetes, chronic heart disease or chronic liver disease, anti-coagulant or anti-platelet treatment, or blood transfusion within the last 3 months. Patients diagnosed with an ovarian mass or adnexial mass, who were then diagnosed postoperatively with paratubal cyst, para-ovarian cyst, myoma or tubo-ovarian abscess, were also excluded from the study. The patients were separated into 2 groups as Group 1 comprising patients with a diagnosis of GCTO (study group) and Group 2 consisting of patients with a benign ovarian mass (control group).

\section{Measures}

The data of all patients including age, tumor diameter, preoperative laboratory values, postoperative pathology results, history of drug use and chronic diseases were retrieved from the electronic medical records and patient files. Complete blood count (CBC) was analysed with a Cell-Dyn 3700 Hematology Analyzer (Abbott, USA). The platelet and neutrophil counts were divided with lymphocyte count to calculate PLR and NLR, respectively. MPV is a machinecalculated measurement of the average size of platelets found in the blood and is typically included in blood tests as part of the CBC. RDW is a measure of the range of variation of red blood cell volume that is reported as part of a standard CBC. 


\section{Statistical analysis}

All statistical analyses were performed using the Statistical Package for Social Sciences software, version 21.0 (IBM Corp. Released 2012. IBM SPSS Statistics for Windows, Armonk, NY, USA). Before the intergroup comparisons, conformity of the data to normal distribution was evaluated with the Kolmogorov-Smirnov and Shapiro-Wilk tests. Continuous variables were presented as mean $\pm S D$ values and compared with the Student's T-test or Mann-Whitney test. Categorical variables were expressed as percentages (\%) and compared with the chi-square test.

Associations were assessed by correlation analysis and multivariate regression analysis. Predictive values of variables and cut-off values with optimal sensitivity and specificity were established by ROC curves. A value of $p<0.05$ was accepted as statistically significant.

\section{RESULTS}

The study included 34 patients with GCTO (study group) and 158 patients with a benign ovarian mass (control group) who were diagnosed between 2006 and 2015. The masses in the control group were determined as serous cysts in 81 (51\%), mucinous cysts in 49 (31\%), mature cystic teratomas in 22 (14\%) and fibroma in $6(4 \%)$ cases. All the GCTO were adult type. The full blood count test results were analysed using the normality test, and only body mass indices (BMI) showed normal distribution. Therefore, for all comparisons other than BMI, nonparametric tests were used. Statistically signficant differences were determined between the groups in respect of NLR, RDW and PLR (p:0.013, p:0.003, p:0.038, respectively) (Table 1 ).

When the two groups were evaluated together, no correlation was observed using Spearman Correlation analysis between age, BMI, tumour diameter and NLR, PLR and RDW. In the evaluation of the groups separately, a significant positive correlation was determined in the study group between tumour diameter and NLR ( $r s=0.46, p=0.006)$.

ROC curves for NLR and PLR are shown in Figure 1. The AUC values obtained for each parameter are
Table 1. Demographic and hematologic parameters.

\begin{tabular}{|c|c|c|c|}
\hline Parameters & $\begin{array}{c}\text { Group 1 } \\
(n=34) \\
\text { Mean } \pm \text { SD }\end{array}$ & $\begin{array}{c}\text { Group 2 } \\
(n=158) \\
\text { Mean } \pm S D\end{array}$ & $\mathbf{P}$ \\
\hline Age (year) & $51.5 \pm 13.5$ & $36 \pm 12.3$ & $<0.001^{b}$ \\
\hline BMI $\left(\mathrm{kg} / \mathrm{m}^{2}\right)$ & $27.1 \pm 4.7$ & $26.3 \pm 4.8$ & $0.328^{\mathrm{a}}$ \\
\hline Tumor Diameter $(\mathrm{cm})$ & $8.1 \pm 5.5$ & $6.9 \pm 3.5$ & $0.674^{b}$ \\
\hline RDW & $14.4 \pm 2.4$ & $15.3 \pm 2.1$ & $0.003^{b}$ \\
\hline NLR & $2.9 \pm 1.8$ & $2.3 \pm 1.1$ & $0.013^{b}$ \\
\hline PLR & $150.9 \pm 51.9$ & $131 \pm 47.2$ & $0.038^{\mathrm{b}}$ \\
\hline
\end{tabular}

BMI: body mass index, RDW: red cell distribution width, NLR: neutrophil -to- lymphocyte ratio,

PLR: platelet- to- lymphocyte ratio. Group values is given as mean $( \pm S D)$.

a Student T-Test

${ }^{b}$ Mann- Whitney U Test.

Table 2. Area under curve values derived from ROC curves for some parametres.

\begin{tabular}{lcccc}
\hline Variables & AUC & Standard Error & $\mathbf{P}$ & $\begin{array}{c}\text { 95\% Confidence } \\
\text { Interval }\end{array}$ \\
\hline RDW & 0.665 & 0.052 & 0.003 & $0.564-0.766$ \\
NLR & 0.637 & 0.052 & 0.013 & $0.534-0.739$ \\
PLR & 0.614 & 0.053 & 0.038 & $0.510-0.717$ \\
\hline
\end{tabular}

RDW: red cell distribution width, NLR: neutrophil -to- lymphocyte ratio, PLR: platelet -to- lymphocyte ratio.

Table 3. Sensitivity, specificity, PPV and NPV of cutoff points for variables from ROC curve.

\begin{tabular}{lccccc}
\hline Variables & $\begin{array}{c}\text { Cut-off } \\
\text { points }\end{array}$ & $\begin{array}{c}\text { Sensitivity } \\
\text { (\%) }\end{array}$ & $\begin{array}{c}\text { Specificity } \\
\text { (\%) }\end{array}$ & PPV (\%) & NPV (\%) \\
\hline RDW & 14.3 & 67.6 & 65.8 & 29.9 & 90.4 \\
NLR & 2.03 & 61.8 & 56.3 & 23.3 & 87.3 \\
PLR & 129.3 & 58.8 & 57 & 22.7 & 86.5 \\
\hline
\end{tabular}

RDW: red cell distribution width, NLR: neutrophil to lymphocyte ratio, PLR: platelet to lymphocyte ratio, PPV: positive predictive value, NPV: negative predictive value.

shown in Table 2. The highest value was found to be 0.665 for RDW.

Using the ROC curve analysis cut-off values, the sensitivity, specificity, positive (PPV), and negative predictive values (NPV) were calculated (Table 3 ). The cut-off values were determined as 14.3 for RDW, 2.03 for NLR and 129.3 for PLR. Only the cut-off value for RDW was determined with sensitivity and specificity of more than $60 \%$. 


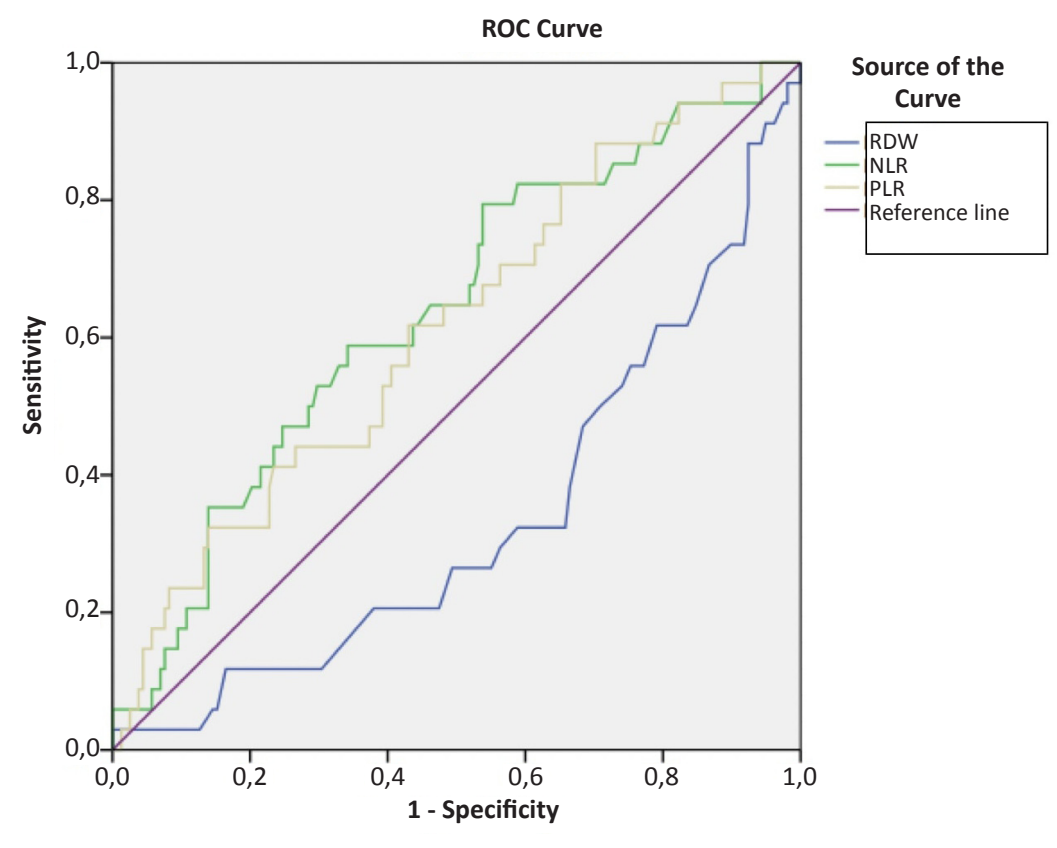

Diagonal segments are produced by ties.

Figure 1. ROC curve for red cell distribution width (RDW), neutrophil to lymphocyte ratio (NLR) and platelet to lymphocyte (PLR).

\section{DISCUSSION}

Mortality rates for ovarian cancer are high as there is no effective screening method and at the time of diagnosis $75 \%$ of patients are at an advanced stage. The risk of ovarian cancer shows an increase for each additional year of approximately $2 \%$ in females aged $<50$ years and $11 \%$ in those aged $\geq 50$ years ${ }^{(14)}$. There are several markers such as Ca-125 and vascular endothelial growth factor (VEGF), that have been studied in the preoperative period for the early diagnosis of ovarian cancer ${ }^{(15)}$. Yeşilyurt et al. evaluated Ca-125 as a marker for GCTO and showed increased mean values in GCTO $(64.5 \pm 130.3 \mathrm{IU} / \mathrm{mL})^{(11)}$.

Recent studies have shown that AMH is beneficial as a tumour marker, especially for GCTO, with sensitivity of $92 \%$ and specificity of $81 \%$ for primary GCTO (16). However, the combined use of $\mathrm{Ca}-125$ and imaging methods, which is still widespread, has come into question. Ca-125 has low sensitivity in early diagnosis and because of the costs of imaging methods, this is not sufficiently robust marker for early diagnosis. Therefore, there is a need for new diagnostic methods that are simple, cheap and reliable to increase the rates of early diagnosis, and the complete blood count (CBC) seems to be suitable for this. It has been reported that some parameters such as platelet counts, NLR, PLR, RDW and the monocyte- to- lymphocyte ratio (MLR) estimated from preoperative $C B C$ values could predict both diagnosis and prognosis in cancer patients ${ }^{(17,18)}$.

As a marker of systemic inflammation, NLR is related to disease severity and prognosis in several different malignancies such as colon, endometrium and ovarian cancer ${ }^{(19-21)}$. In a recent study, NLR was found to be statistically significantly different in GCTO and benign ovarian masses. ROC curve analysis has shown that NLR could be a differentiating factor in the preoperative prediction of GCTO ${ }^{(11)}$. In a more recent meta-analysis, a significant relationship was determined between high NLR and poor general survival (HR: 1.88, 95\% Cl 1.30-.73) and shorter progression-free survival (HR 1.65, $95 \% \mathrm{Cl} 1.18$ 2.29). In addition, increased NLR was found to be significantly correlated (-3.04) with tumour size (OR 2.05, 95\% Cl 1.14-3.65), advanced FIGO stage (OR $2.12,95 \% \mathrm{Cl} 1.28-3.49)$ and lymph node involvement (OR 2.24, 95\% Cl 1.65) ${ }^{(22) .}$

However, the underlying mechanisms of the relati- 
onship between high NLR and poor outcomes in cancer patients are still not sufficiently understood. Several cancer studies have used NLR in the prediction of survival, but the wide range of cut-off values reported as 1.9-5.020 restrict its use in this area ${ }^{(23)}$. In the current study, the NLR cut-off value was determined as 2.03 .

In previous studies in the literature, a relationship has been found between high RDW levels and atherosclerosis, inflammatory intestinal diseases, prostate cancer, oesophageal carcinoma, upper urinary system urothelial carcinoma and endometrial cancer ${ }^{(24-28)}$. In addition, oxidative stress and inflammation have been shown to affect RDW but this relationship has not been well defined ${ }^{(13,29)}$.

A meta-analysis reported that RDW was a strong determinant of mortality in elderly adults with and without age-related diseases such as cardiovascular diseases and cancers ${ }^{(12,13)}$. Although the underlying biological mechanism of this relationship is not clear, it is probably related to the role of cytokines in circulation, such as systemic expressions of IL- 6 , TNF- $\alpha$, and hepcidin ${ }^{(30,31)}$. Finally, increased RDW has been shown in conditions of increasing mortality in literature. In the current study, RDW could have been low as there was no life-threatening condition. On the ROC curve, the RDW curve was observed to be on the right of the reference curve, as small values for RDW were selected for GCTO (Figure 1). Furthermore, oestrogen, anti-oxidant, pro-inflammatory and antiinflammatory effects could have been responsible for the decrease in RDW and increase in NLR.

As it has a low prevalence in general population, any screening test for ovarian malignant tumors, such as ovarian cancer to achieve a positive predictive value of $10 \%$, should have at least $75 \%$ sensitivity and $99.6 \%$ specificity. This means that maximum 10 surgical procedures should be performed to find one cancer case. RDW is not suitable as a screening test because the ROC curve analysis showed that the best cut-off value had test sensitivity in the range of $60 \%-65 \%$. This is far too low in clinical practice when compared to the predictive values of many existing ultrasound-based models such as the IOTA group's LR1, LR2, the Simple Rules or ADNEX, mixed models, such as various RMIs and serum tumor marker- based models such as ROMA or OVA1.

In conclusion, herein we found an increase in NLR and PLR and a decrease in RDW in GCTO. To the best of our knowledge, this is the first study which evaluated RDW in the diagnosis of GCTO. Of these 3 parameters, although RDW should not be used in differential diagnosis for GCTO because of the low sensitivity and specificity values, it could be a simple, low-cost preoperative test for screening. In addition, as the GCTO diameter increased, a statistically significant increase was observed in NLR. Nevertheless, there is a need for further randomised controlled studies on this subject.

Ethics Committee Approval: Approval was obtained from the Zeynep Kamil Gynecology and Pediatrics Training and Research Hospital Clinical Research Ethics Committee (Decision no 163 / 06.11.2015).

Conflict of Interest: No author has any potential conflict of interest and granted support.

Funding: None

Informed Consent: Informed consent was taken from all the participants.

\section{REFERENCES}

1. Malmstrom H, Hogberg T, Risberg B, Simonsan E. Granulosa cell tumors of the ovary: Prognostic factors and outcome. Gynecol Oncol. 1994;52:50-5. https://doi.org/10.1006/gyno.1994.1010

2. Schumer ST, Cannistra SA. Granulosa cell tumor of the ovary. J Clin Oncol. 2003;21:1180-9.

https://doi.org/10.1200/JCO.2003.10.019

3. Segal R, De Petrillo AD, Thomas G. Clinical review of adult granulosa cell tumors of the ovary. Gynecol Oncol. 1995;56:338-44. https://doi.org/10.1006/gyno.1995.1060

4. Crigler JF, Vawter GF. Granulosa theca cell tumors in premenarchal girls: A clinical and pathologic study of ten cases. Cancer. 1981;48:1846-54. https://doi.org/10.1002/1097-0142(19811015)48:8<1846: AID-CNCR2820480823>3.0.CO;2-T

5. Young RH, Dickersin GR, Scully RE. Juvenile granulosa cell tumor of the ovary. A clinico-pathological analysis of 125 cases. Am J Surg Pathol. 1984;8:575-96. https://doi.org/10.1097/00000478-198408000-00002

6. Allavena P, Sica A, Solinas G, et al. The inflammatory microenvironment in tumor progression: The role of tumorassociated macrophages. Crit Rev Oncol Hematol. 2008;66(1):1-9. https://doi.org/10.1016/j.critrevonc.2007.07.004

7. Reuter S, Gupta SC, Chaturvedi MM, et al. Oxidative stress, inflammation, and cancer: How are they linked?. Free Radic Biol Med. 2010;49(11):1603-16. https://doi.org/10.1016/j.freeradbiomed.2010.09.006

8. Polat M, Senol T, Ozkaya E, et al. Neutrophil to lymphocyte and platelet to lymphocyte ratios increase in ovarian tumors in the presence of frank stromal invasion. Clin Transl Oncol. 
2016;18(5):457-63. https://doi.org/10.1007/s12094-015-1387-7

9. Acmaz G, Aksoy H, Unal D, et al. Are neutrophil/lymphocyte and platelet/lymphocyte ratios associated with endometrial precancerous and cancerous lesions in patients with abnormal uterine bleeding? Asian Pac J Cancer Prev. 2014;15:168992.

https://doi.org/10.7314/APJCP.2014.15.4.1689

10. Yildirim MA, Seckin KD, Togrul $C$, et al. Roles of neutrophil/ lymphocyte and platelet/lymphocyte ratios in the early diagnosis of malignant ovarian masses. Asian Pac J Cancer Prev. 2014;15(16):6881-5. https://doi.org/10.7314/APJCP.2014.15.16.6881

11. Yesilyurt H, Tokmak A, Guzel Al, et al. Parameters for predicting granulosa cell tumor of the ovary: a single center retrospective comparative study. Asaian Pac J Cancer Prev. 2014;15(19):8447-50 https://doi.org/10.7314/APJCP.2014.15.19.8447

12. Perlstein TS, Weuve J, Pfeffer MA, Beckman JA. Red blood cell distribution width and mortality risk in a community-based prospective cohort. Arch Intern Med. 2009;169:588-94. https://doi.org/10.1001/archinternmed.2009.55

13. Patel KV, Semba RD, Ferrucci L, et al. Red cell distribution width and mortality in older adults: A meta-analysis. J Gerontol A Biol Sci Med Sci. 2010;65:258-65. https://doi.org/10.1093/gerona/glp163

14. Gates MA, Rosner BA, Hecht JL, Tworoger SS. Risk factors for epithelial ovarian cancer by histologic subtype. Am J Epidemiol. 2010;171(1):45-53. https://doi.org/10.1093/aje/kwp314

15. Cooper BC, Ritchie JM, Broghammer CL, et al. Preoperative serum vascular endothelial growth factor levels: significance in ovarian cancer. Clin Cancer Res. 2002;8(10):3193-7.

16. Färkkilä $A$, Koskela $S, B r y k S$, et al. The clinical utility of serum anti- Müllerian hormone in the follow-up of ovarian adulttype granulosa cell tumors-A comparative study with inhibin B. Int J Cancer. 2015;137(7):1661-71. https://doi.org/10.1002/ijc.29532

17. Ueno $\mathrm{H}$, Hawrylowicz CM, Banchereau J. Immunological intervention in human diseases. J Transl Med. 2007;5(1):59. https://doi.org/10.1186/1479-5876-5-59

18. Riedl J, Posch F, Königsbrügge $O$, et al. Red cell distribution width and other red blood cell parameters in patients with cancer: Association with risk of venous thromboembolism and mortality. PloS One. 2014;9(10):e111440. https://doi.org/10.1371/journal.pone.0111440

19. Suh $\mathrm{DH}$, Kim HS, Chung $\mathrm{HH}$, et al. Pre-operative systemic inflammatory response markers in predicting lymph node metastasis in endometrioid endometrial adenocarcinoma. Eur J Obstet Gynecol Reprod Biol. 2012;162(2):206-10. https://doi.org/10.1016/j.ejogrb.2012.02.028

20. Mallappa S, Sinha A, Gupta S, Chadwick SJD. Preoperative neutrophil to lymphocyte ratio> 5 is a prognostic factor for recurrent colorectal cancer. Colorectal Dis. 2013;15(3):323-8. https://doi.org/10.1111/codi.12008

21. Williams KA, Labidi-Galy SI, Terry KL, et al. Prognostic significance and predictors of the neutrophil-to-lymphocyte ratio in ovarian cancer. Gynecol Oncol. 2014;132(3):542-50. https://doi.org/10.1016/j.ygyno.2014.01.026

22. Huang QT, Man QQ, Hu J, et al. Prognostic significance of neutrophil-to-lymphocyte ratio in cervical cancer: A systematic review and meta-analysis of observational studies. Oncotarget. 2017;8(10):16755-64. https://doi.org/10.18632/oncotarget.15157

23. Templeton AJ, McNamara MG, Šeruga B, et al. Prognostic role of neutrophil-to-lymphocyte ratio in solid tumors: A systematic review and meta-analysis. J Natl Cancer Inst. 2014; 106(6):dju124. https://doi.org/10.1093/jnci/dju124

24. Karabulut A, Uzunlar B. Correlation between red cell distribution width and coronary ectasia in the acute myocardial infarction. Clin Appl Thromb Hemost. 2012;18:551-2. https://doi.org/10.1177/1076029611436198

25. Yesil A, Senates E, Bayoglu IV, Erdem ED, Demirtunç R, Kurdaş Övünç AO. Red cell distribution width: A novel marker of activity in inflammatory bowel disease. Gut Liver. 2011;5: 460-7. https://doi.org/10.5009/gnl.2011.5.4.460

26. Albayrak S, Zengin K, Tanik S, Bakirtas H, Imamoglu A, Gurdal M. Red cell distribution width as a predictor of prostate cancer progression. Asian Pac J Cancer Prev. 2014;15:7781-4. https://doi.org/10.7314/APJCP.2014.15.18.7781

27. Cheng YC, Huang CN, Wu WJ, et al. The prognostic significance of inflammation-associated blood cell markers in patients with upper tract urothelial carcinoma. Ann Surg Oncol. 2016;23(1):343-51. https://doi.org/10.1245/s10434-015-4781-z

28. Kemal Y, Demirag G, Baş B, Önem S, Teker F, Yücel İ. The value of red blood cell distribution width in endometrial cancer. Clin Chem Lab Med. 2015;53(5):823-7. https://doi.org/10.1515/cclm-2014-0699

29. Semba RD, Patel KV, Ferrucci L, et al. Serum antioxidants and inflammationpredict red cell distribution width in older women: The Women's Health and Aging Study I. Clin Nutr. 2010;29(5):600-4. https://doi.org/10.1016/j.clnu.2010.03.001

30. De Gonzalo-Calvo D, de Luxán-Delgado B, Rodríguez-González $S$, et al. Interleukin 6 , soluble tumor necrosis factor receptor I and red blood cell distribution width as biological markers of functional dependence in an elderly population. A translational approach. Cytokine. 2012;58:193-8. https://doi.org/10.1016/j.cyto.2012.01.005

31. Rhodes CJ, Howard LS, Busbridge M, et al. Iron deficiency and raised hepcidin in idiopathic pulmonary arterial hypertension: Clinical prevalence, outcomes, and mechanistic insights. J Am Coll Cardiol. 2011;58:300-9. https://doi.org/10.1016/j.jacc.2011.02.057 